(C) Inra/Elsevier, Paris

Original article

\title{
Screening barley germplasm for resistance to a new isolate of barley yellow mosaic virus (BaYMV)
}

\author{
Boubker Bensalah $^{\mathrm{a}, \mathrm{b}}$, Fernand Froidmont ${ }^{\mathrm{a}}$, Jean-Marie Jacquemin ${ }^{\mathrm{a}^{*}}$ \\ ${ }^{a}$ Station d'amélioration des plantes, Centre de recherches agronomiques, rue du Bordia, 4, 5030 Gembloux, Belgium \\ ${ }^{\mathrm{b}}$ Laboratoire de pathologie végétale, faculté des sciences agronomiques de Gembloux, \\ rue Maréchal Juin, 13, 5030 Gembloux, Belgium
}

(Received 7 July 1997; accepted 6 February 1998)

\begin{abstract}
Resistance to a new isolate of barley yellow mosaic virus was evaluated within barley germplasm under field conditions. At Huccorgne, the cultivars 'Comte de Serres', 'Marne', 'Jochiweon covered', 'Mushinchiang3', etc., or lines 'L 541', 'RDA 72.49' are potential sources of resistance against this isolate. In some cultivars or lines, this resistance can be detected using a RFLP marker (MWG10), linked to $y m 4$, the recessive gene conferring resistance to barley yellow mosaic and barley mild mosaic virus. It is shown that in some barley lines resistant to the new isolate, this probe detects an allele of approximately $2.7 \mathrm{~kb}$. In other resistant varieties, the gene involved is independent of $y m 4$. The segregation in the $\mathrm{F}_{2}$ population of a cross ' $\mathrm{L} 54 \mathrm{I}^{\prime} \times$ 'Travelling' showed that resistance in ' $\mathrm{L} 54 \mathrm{l}$ ' is conferred by a single recessive gene. (@ Inra/Elsevier, Paris.)
\end{abstract}

\section{Hordeum vulgare / barley yellow mosaic virus / resistance gene / germplasm / RFLP marker}

Résumé - Évaluation de la résistance à un nouvel isolat du virus de la mosaïque jaune de l'orge (BaYMV). La résistance à un nouvel isolat du virus de la mosaïque jaune de l'orge a été évaluée dans une collection d'orge, en conditions naturelles. A Huccorgne, les variétés «Comte de Serres», « Marne», «Jochiweon covered», « Mushinchiang3»..., ou les lignées «L 541 », «RDA 72.49» sont des sources de résistance potentielle contre cet isolat. Chez certains cultivars ou lignées, cette résistance peut être détectée en utilisant le marqueur RFLP MWG10, lié au gène récessif ym4, conférant la résistance aux virus de la mosaïque modérée et de la mosaïque jaune de l’orge. Il est montré que chez quelques lignées d'orge résistantes au nouvel isolat, cette sonde détecte une allèle à environ $2,7 \mathrm{~kb}$. Chez d'autres variétés résistantes, le gène impliqué est indépendant de ym4. La ségrégation dans la population $\mathrm{F} 2$ du croisement « $\mathrm{L} 541$ » $\times$ «Travelling» montre que la résistance de L 541 est conférée par un gène récessif. (@ Inra/Elsevier, Paris.)

Hordeum vulgare / virus de la mosaïque jaune de l'orge / gène de résistance / germoplasme / marqueurs RFLP

Communicated by André Gallais (Gif-sur-Yvette)

* Correspondence and reprints

Tel.: (32) 81612491 ; fax: (32) 81615863 


\section{INTRODUCTION}

Barley yellow mosaic is an important disease of winter barley in Europe and Japan. The virus disease, transmitted through the soilborne fungus Polymyxa graminis, was found in several countries: Germany [15], England [10], France [19] and Belgium [20]. In these countries, studies conducted in field infection conditions, have indicated the presence of different types of viruses [11,23]. The differences observed at the level of biological and serological properties [1], as well as for the density of virus particles [12] and nucleotide sequences [2], led Huth and Adams [14] to conclude the existence of two different viruses named barley yellow mosaic virus (BaYMV) and barley mild mosaic virus (BaMMV).

In barley breeding, the most widely used source of resistance to barley yellow mosaic virus disease is originated from the variety 'Ragusa' that possesses a recessive gene (ym4) which confers complete immunity to BaYMV and BaMMV. Ordon and Friedt [21] and Götz and Friedt [4] carried out a survey in order to find new genes conferring resistance to the virus complex. Recently, one new viral type which overcomes the classical resistance conferred by $y m 4$ has been characterized in some countries. In Germany this new isolate was called BaYMV-2 owing to its close relationship with BaYMV [8, 13]. An isolate has also been found in Belgium which does not show any cross-serological reactions with monoclonal antibodies raised against BaYMV and BaMMV [17, 22]. Partial sequencing of genomic RNA of this isolate [18] revealed that it is closely related to BaYMV-2 [3].

In a general effort to map the barley genome, several groups have reported RFLP maps: Graner et al. [6], Heun et al. [9] and Kleinhofs et al. [16]. More recently, Graner and Bauer [5] succeeded in mapping the $y m 4$ gene and found the MWG10 probe which differentiates between the resistant and the susceptible barley cultivars to BaYMV and BaMMV.

In this study, we describe the results of several barley varieties screening for resistance to the new resistance-breaking isolate of BaYMV and their molecular characterization by using the MWG10 probe. We have also identified the inheritance of the resistance in an $F_{2}$ population from a cross between ' $\mathrm{L} 541$ ' (resistant to the barley mosaic virus complex) and 'Travelling' (susceptible).

\section{MATERIALS AND METHODS}

Plants from 26 barley cultivars or breeding lines were sown in two different selected fields located at Huccorgne (contaminated with the common strains BaYMV, BaMMV and a new viral isolate named BaYMV-EH) and in Gembloux (contaminated with BaYMV and BaMMV), respectively. Symptoms were regularly inspected during the growing season and visual scores, along with ELISA readings, were used to assess the reaction. For the characterization of the resistant genotypes at the molecular level, these were analysed by Southern hybridization. Large-scale DNA preparation was performed from $0.5-1 \mathrm{~g}$ of leaves. These were ground in powder in liquid nitrogen and resuspended in $100 \mathrm{~mL}$ Tris- $\mathrm{HCl}, \mathrm{NaCl} 100 \mathrm{~mL}, 50 \mathrm{~mL}$ EDTA, SDS $2 \%, \mathrm{pH} 8.0$. Extraction was performed with an equal volume of phenol/chloroform/isoamylalcohol 25:24:1. After centrifugation, the aqueous phase was precipitated by cold ethanol. The DNA was scooped with a spatula and resuspended in TE $(10 \mathrm{mM}$ Tris-HCl, 1 mM EDTA pH 7.5).

A sample of $10 \mu \mathrm{g}$ of DNA was digested by BamHI restriction enzyme with the appropriate buffer and loaded on a $0.8 \%$ agarose gel. After electrophoresis, DNA fragments were transferred by Southern blotting onto nylon membranes (Hybond $\mathrm{N}+$, Amersham), and were treated with $0.4 \mathrm{M} \mathrm{NaOH}$ for DNA fixation. Cloned MWG10 insert was excised from plasmid and radioactively labelled by random priming according to the Boehringer protocol. Hybridization was performed in $4 \times \mathrm{SSC}$ at $65^{\circ} \mathrm{C}$ for $16 \mathrm{~h}$ and membranes were washed successively with $2 \times \mathrm{SSC} / 0.1 \% \mathrm{SDS}, 1 \times$ $\mathrm{SSC} / 0.1 \% \mathrm{SDS}$ and finally exposed to X-ray film.

To observe the segregation of the new resistance gene, we performed a cross between ' $L 541$ ' and 'Travelling', 100 and 106 plants of the $F_{2}$ population were analysed in Gembloux and Huccorgne, respectively.

\section{RESULTS}

In Belgium, a preliminary survey for the presence of a new viral resistance-breaking isolate 
(such as BaYMV-2), using the variety 'Express' as reporter, has shown that a virus (called BaYMV$\mathrm{EH}$ ) was present in one contaminated field (in Huccorgne). Symptoms observed on the cultivar Express are different from those induced by BaYMV or BaMMV on sensitive barley cultivars.

In order to increase the diversity of useful genes for resistance to the barley mosaic virus complex, an evaluation of the resistance of 26 selected barley varieties or lines, originated from different parts of the world, was performed in natural field infection, in two sites (Huccorgne and Gembloux). Table I shows the different lines tested and their status: resistant or susceptible in the two localities.
The cultivars and lines 'Comte de Serres', 'Marne', 'Escourgeon de Champagne', 'Super Champenois', 'Ile de Ré', 'Jochiweon covered', 'Mushinchiang 3', 'L 541' and 'RDA 72.49' showed resistance to BaYMV, BaMMV and to the new virus isolate (BaYMV-EH), while 'Neger' and 'Mielmont' were susceptible to the virus complex, presenting similar reactions to the controls: 'Gerbel', 'Truitel' and 'Arton'. The cultivars 'Express', 'Melusine', 'Target', 'L 28.28', 'Bison', 'Gaulois', 'Franka', 'Torrent', 'Nordic', 'Energie', 'Turkey 524' and 'Hatif de Grignon' were only resistant to the common strains of yellow mosaic disease, but were susceptible to BaYMV-EH. Moreover, ELISA tests were performed (results not

Table I. Reactions of the different lines and varieties tested at Gembloux and Huccorgne against barley mosaic viral complex and size of the informative fragment detected after hybridization with probe MWG10.

\begin{tabular}{lccc}
\hline Varieties and lines tested & $\begin{array}{c}\text { Huccorgne } \\
\text { Status of variety }\end{array}$ & $\begin{array}{c}\text { Gembloux } \\
\text { Status of variety }\end{array}$ & $\begin{array}{c}\text { Fragment size (kb) } \\
\text { (informative fragment) }\end{array}$ \\
\hline Jochiweon covered & $\mathrm{R}$ & $\mathrm{R}$ & 2.7 \\
Mushinchiang 3 & $\mathrm{R}$ & $\mathrm{R}$ & 2.2 \\
Turkey 524 & $\mathrm{S}$ & $\mathrm{R}$ & 2.2 \\
Express & $\mathrm{S}$ & $\mathrm{R}$ & 1.8 \\
Melusine & $\mathrm{S}$ & $\mathrm{R}$ & 1.8 \\
Target & $\mathrm{S}$ & $\mathrm{R}$ & 1.8 \\
L 28.28 & $\mathrm{S}$ & $\mathrm{R}$ & 1.8 \\
Hatif de Grignon & $\mathrm{S}$ & $\mathrm{R}$ & 2.2 \\
Marne & $\mathrm{R}$ & $\mathrm{R}$ & 2.2 \\
Bison & $\mathrm{S}$ & $\mathrm{R}$ & 1.8 \\
Ile de Ré & $\mathrm{R}$ & $\mathrm{R}$ & 2.2 \\
Escourgeon de Champagne & $\mathrm{R}$ & $\mathrm{R}$ & 2.2 \\
Super Champenois & $\mathrm{R}$ & $\mathrm{R}$ & 2.2 \\
Gaulois & $\mathrm{S}$ & $\mathrm{R}$ & 1.8 \\
Comte de Serres & $\mathrm{R}$ & $\mathrm{R}$ & 2.2 \\
Franka & $\mathrm{S}$ & $\mathrm{R}$ & 1.8 \\
L541 & $\mathrm{R}$ & $\mathrm{R}$ & 2.7 \\
Arton & $\mathrm{S}$ & $\mathrm{S}$ & 2.2 \\
RDA72.49 & $\mathrm{R}$ & $\mathrm{R}$ & $2.7-2.2$ \\
Neger & $\mathrm{S}$ & $\mathrm{S}$ & 2.2 \\
Torrent & $\mathrm{S}$ & $\mathrm{R}$ & 1.8 \\
Gerbel & $\mathrm{S}$ & $\mathrm{S}$ & 2.2 \\
Truitel & $\mathrm{S}$ & $\mathrm{S}$ & 2.2 \\
Mielmont & $\mathrm{S}$ & $\mathrm{S}$ & 2.2 \\
Nordic & $\mathrm{S}$ & $\mathrm{R}$ & 1.8 \\
Energie & $\mathrm{S}$ & $\mathrm{R}$ & 1.8 \\
\hline
\end{tabular}

R: resistant; S: susceptible. 


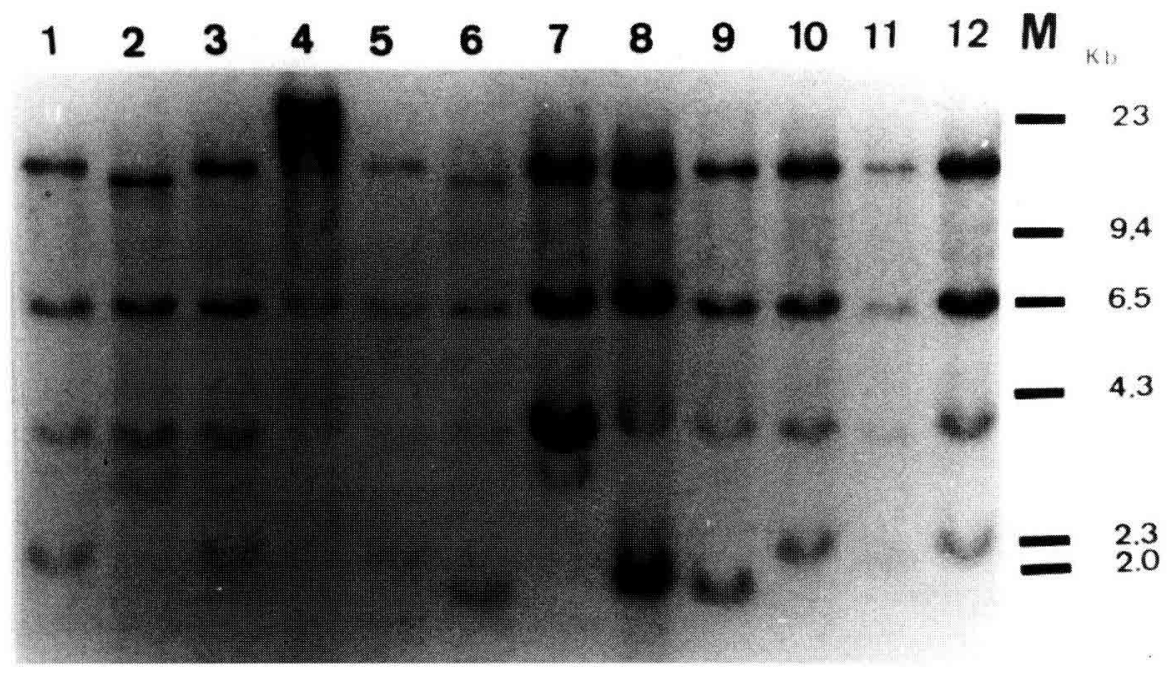

Figure 1. Results observed for Southern analysis using probe MWGI0 of BamHI digested DNA from the barley cultivars. Legend: 1: Turkey 524; 2: Jochiweon Covered; 3: RDA 72.49; 4: Île de Ré; 5: Escourgeon de Champagne; 6: $\mathrm{L}$ 28.28; 7: L 541; 8: Franka; 9: Express; 10: Travelling; 11: Truitel; 12: Gerbel. M: DNA size marker / Hind III digested (23. 1, 9.4, 6.7, 4.4, 2.3, 2.0 kb).

shown) on plants grown in the field located in Huccorgne; only five cultivars or lines presented serological reactions with anti-BaMMV and/or anti-BaYMV monoclonal antibodies, whereas 12 cultivars showed clear mosaic symptoms and nine cultivars or lines showed no symptoms. On the contrary, a total correlation was observed between ELISA test results and mosaic symptom observations for plants from the field located in Gembloux.

We performed Southern blot hybridization with MWG10 probe, linked to the $y m 4$ gene. As previously shown by Graner and Bauer [5], a clear pattern difference between susceptible and resistant plants was obtained using this probe. Figure I presents the results obtained with some of the varieties and table $I$ lists all the patterns observed.

Table I shows that in the genotypes 'Express', 'Melusine', 'Target', 'L 28.28', 'Bison', 'Gaulois', 'Franka', 'Torrent', 'Nordic' and 'Energie', a fragment of $1.8 \mathrm{~kb}$, characterizing resistant genotypes bearing $y m 4$, is detected. A $2.2-\mathrm{kb}$ band is revealed in the varieties 'Truitel', 'Gerbel', 'Arton' and 'Travelling' which are susceptible to all strains of barley yellow mosaic. However, our results showed that the presence of the 2.2-kb band is not only related to susceptibility. Indeed, this band at $2.2 \mathrm{~kb}$ is present in genotypes 'Comte de Serres', 'Marne', 'Escourgeon de Champagne', 'Super Champenois', 'Ile de Ré', resistant to the new viral complex of yellow mosaic disease with BaYMV-
EH and also in genotypes 'Turkey 524' and 'Hatif de Grignon' resistant to the common strains with BaYMV. Moreover, these results also show that in the new resistant genotypes 'Jochiweon Covered', 'L.541' and 'RDA 72.49', a new band is detected at $2.7 \mathrm{~kb}$ instead of $1.8 \mathrm{~kb}$.

In order to investigate the genetic basis of this resistance, we evaluated the viral resistance and the segregation of the $2.7-\mathrm{kb}$ allele on a $\mathrm{F}_{2}$ population constituted by crossing 'L 54l' with 'Travelling'. As the resistance conferred by the new allele is also effective against BaYMV and BaMMV, the $F_{2}$ population was tested in infected fields located in Gembloux (BaYMV and BaMMV) and in Huccorgne (BaYMV, BaMMV and BaYMV-EH) for symptom evaluation. Based on symptoms, the plants grown in the fields at Gembloux and Huccorgne showed similar levels of infection by the virus complex of barley mosaic, on average estimated to be $74 \%$. The results showed that in Huccorgne and Gembloux, the $\mathrm{F}_{2}$ segregation fitted the $1 \mathrm{R}: 3 \mathrm{~S}$ ratio, indicating that the new gene acts in a recessive manner (table II).

The resistance trait was confirmed by serological test (ELISA) applied to plants from Gembloux (table III). In Huccorgne, owing to the lack of an antibody against BaYMV-EH, the confirmation of the $1 \mathrm{R}: 3 \mathrm{~S}$ ratio was based only on symptoms observed. 
Table II. Segregation of $F_{2}$ population from cross ' $L 541$ ' $(\mathrm{Pr}) \times$ 'Travelling' (Ps) at Gembloux and Huccorgne for reaction to barley mosaic virus complex.

\begin{tabular}{lcccccc}
\hline & \multicolumn{2}{c}{ Segregation observed } & $\%$ & $\chi_{1: 3}^{2}$ & $P$ & $N$ \\
Site & Susceptible & Resistant & & & & \\
\hline Gembloux & 74 & 26 & 74 & 0.013 & $0.90-0.95$ & 100 \\
Huccorgne & 79 & 27 & 74.5 & 0.012 & $0.90-0.95$ & 106 \\
\hline
\end{tabular}

$N$ : total of $\mathrm{F}_{2}$ population, $P$ : probability of the observed $\chi^{2}$.

Table III. Segregation ratio of $F_{2}$ progeny from cross ' $L$ 541' $(\mathrm{Pr}) \times$ 'Travelling' (Ps) based on ELISA readings at Gembloux and Huccorgne.

$$
\text { Gembloux }(N=102) \quad \text { Huccorgne }(N=106)
$$

\begin{tabular}{lccccc} 
& Positive test & $\%$ & $\chi_{1: 3}^{2}$ & Positive test & $\%$ \\
\hline BaMMV & 67 & 65.7 & & 16 & 15.1 \\
BaYMV & 39 & 38.2 & & 39 & 36.8 \\
BaMMV+BaYMV) & 35 & 34.3 & & 7 & 6.6 \\
BaMMV and /or BaYMV & 71 & 69.6 & 1.3 & 48 & 45.3 \\
\hline
\end{tabular}

$N$ : total of the $\mathrm{F}_{2}$ population analysed with ELISA test. Remark: BaYMV-EH at Huccorgne was characterized with visual symptoms of the $\mathrm{F}_{2}$ plants (28 plants).

The results of the serological tests showed that in Gembloux, 65.7 and $38.2 \%$ of the $F_{2}$ plants were infected by BaMMV and BaYMV, respectively, while $34.3 \%$ were infected by both BaMMV and BaYMV. In total, $69.6 \%$ were infected by one or the other or both common strains of barley mosaic virus at this site. These ELISA test readings fit well to the visual scorings (tables $I I$ and III).

In Huccorgne, the serological results showed that 15.1 and $36.8 \%$ of plants were infected by BaMMV and BaYMV, respectively, and only 6.6 $\%$ by both common strains. In total, $45.3 \%$ were infected. The 28 remaining plants $(26.4 \%)$ that have shown susceptibility could not be confirmed by ELISA test (table III).

Based on DNA hybridization experiments, applied to plants sown in Huccorgne figure 2 and table $V$ ), a single $2.7-\mathrm{kb}$ band was detected in 24.5 $\%$ of the $\mathrm{F}_{2}$ plants and these have the genotype of the resistant parent (' $\mathrm{L} 541$ '). A single $2.2-\mathrm{kb}$ band was detected in $28.4 \%$ of the $\mathrm{F}_{2}$ plants and $42.2 \%$ were heterozygous, as shown by the codominant presence of the two 2.2- and 2.7-kb bands. Five plants $(4.9 \%)$ were heterozygous, even though they were classified as resistant based on visual scorings and serological tests.

By Southern hybridization with probe MWG10 on the plants grown in Gembloux (table IV), 20.6 $\%$ showed one band at $2.7 \mathrm{~kb}$ characterizing the resistant phenotype, $22.5 \%$ showed one band at $2.2 \mathrm{~kb}$ characterizing the susceptible phenotype; 50 $\%$ were heterozygous and $6.9 \%$ (seven plants) classified as resistant were also heterozygous.

The molecular analysis fits well the visual scores in the field and the results of serological tests conducted on $\mathrm{F}_{2}$ population at Gembloux and Huccorgne. Cosegregation of the MWG10 marker and the resistant gene is shown in tables $I V$ and $V$ at Gembloux and Huccorgne, respectively. The analysis of segregation fits to a 1:2:1 ratio showing 


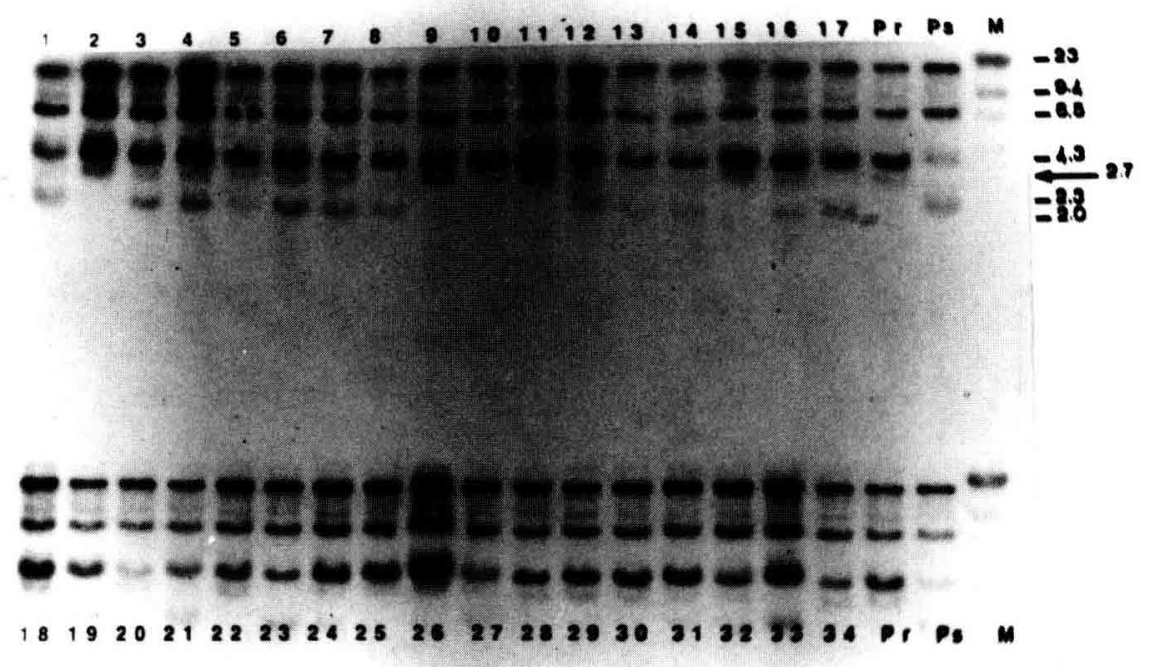

Figure 2. Autoradiography for Southern analysis using probe MWG10 of BamHI digested DNA from $34 \mathrm{~F}_{2}$ plants and the parents of the cross ' $L 541^{\prime} \times$ 'Travelling'. Pr: resistant parent (L 541); Ps: susceptible parent (Travelling); $1 \rightarrow 34:$ plants $F_{2}$.

Table IV. Distribution of genotype at the MWG10 locus and of the resistance against barley mosaic virus complex in a $\mathrm{F}_{2}$ population at Gembloux.

\begin{tabular}{lcccccc}
\hline Gembloux & Resistant & Susceptible & $\%$ & $N$ & $\chi^{2}$ & $P$ \\
\hline Allele $2.7 \mathrm{~kb}$ & 21 & - & 20.6 & & & \\
Allele $2.2 \mathrm{~kb}$ & $\overline{7}$ & 23 & 22.6 & 102 & 2.0 & $0.30-0.40$ \\
Heterozygous & 51 & 56.8 & & & \\
\hline
\end{tabular}

$N$ : total of the $\mathrm{F}_{2}$ plants; $P$ : probability of the observed $\chi^{2}$.

Table V. Distribution of genotype at the MWG10 locus and of the resistance against barley mosaic virus complex in a $\mathrm{F}_{2}$ population at Huccorgne.

\begin{tabular}{lcccccc}
\hline Huccorgne & resistant & susceptible & $\%$ & $\mathrm{~N}$ & $\chi^{2}$ & $\mathrm{P}$ \\
\hline Allele $2.7 \mathrm{~kb}$ & 25 & - & 24.5 & & & \\
Allele $2.2 \mathrm{~kb}$ & $\overline{5}$ & 29 & 28.5 & 102 & 0.67 & $0.70-0.80$ \\
Heterozygous & 43 & 47.0 & & & \\
\hline
\end{tabular}

$N$ : total of the $F_{2}$ plants; $P$ : probability of the observed $\chi^{2}$.

that the resistance in ' $\mathrm{L} 541$ ' is due to a single recessive gene.

\section{DISCUSSION}

Resistance to BaYMV and BaMMV was first shown to be associated with the $y m 4$ gene and recently, in a more diverse manner, with several different genes [7]. Most of the resistant varieties showed, in genetic analysis, a segregation pattern consistent with recessive genes. The $y m 4$ gene is classically used in barley breeding in Europe; apparition of a new type of virus which bypasses the resistance conferred by this gene, as shown in 
Huccorgne, calls for a research of new sources of resistance.

The infection rate, close to $100 \%$, is high enough to discriminate susceptible and resistant genotypes in field for both genetic studies and searching for new sources of resistance. Comparative examination of the results obtained in the two localities shows the susceptibility to BaMV-EH of some cultivars such as 'Express', 'Franka' and 'Gaulois' known to be resistant in Gembloux to the BaMMV and BaYMV. Some tested cultivars are sensitive, for example 'Turkey 524', 'Target', 'Melusine', 'Bison' and 'L 28.28'. Meanwhile, several other varieties such as 'Comte de Serres', 'Escourgeon de Champagne', 'Ile de Re', 'Jochiweon Covered', 'L 541', 'Marne', 'Mushinchiang 3', 'RDA 72.49' and 'Super Champenois', are resistant to BaMMV, BaYMV and to the new isolate of the virus (BaYMV-EH) that has appeared in Huccorgne.

When these resistant varieties are analysed by Southern hybridization with probe MWG10, a new band at $2.7 \mathrm{~kb}$, instead of $1.8 \mathrm{~kb}$, is detected for some of the resistant lines. Moreover in the resistant varieties, such as 'Comte de Serres', the probe detects a band at $2.2 \mathrm{~kb}$ indicating that the allele for susceptibility was present at the Ym4 locus, and that the gene responsible for resistance in this variety is not detected by the MGW10 probe, and must therefore be located at another locus in the barley genome or have another structure. Similar results are obtained with varieties resistant to the new type of virus (BaYMV-EH) such as 'Escourgeon de Champagne', 'Marne', 'Ile de Re', 'Mushinchiang 3', 'Super Champenois' or only to the common strains (BaMMV and BaYMV) such as 'Hatif de Grignon' and 'Turkey 524'.

On the other hand, we can observe the presence of the two alleles, the sensitive one at $2.2 \mathrm{~kb}$ and the resistant one at $2.7 \mathrm{~kb}$ in 'RDA 72.49' (developed by backcross with a parent with agronomic value), indicating that this line was in fact still at the heterozygous stage. The results reported above can be of practical use because some resistant lines, such as 'RDA 72.49' already have some good agronomic traits valuable in the European environments. Moreover, as the classical selection in infected fields is more difficult to carry in the presence of this new BaYMV-EH isolate owing to a more labile symptomatology than in the case of BaMMV and BaYMV infection, the use of gene identification with probe MWG10 is valuable.

The ratio observed in the $F_{2}$ population fits $1 R$ to $3 \mathrm{~S}$ indicating a recessive inheritance. Based on molecular analysis, the mode of inheritance of this resistance trait was also recessive. The MWG10 RFLP marker allows clearly, in the (L541 $\times$ Travelling) $F_{2}$ population to discriminate the resistant and sensitive progeny. This RFLP marker maps at $1.4 \mathrm{cM}$ of $y m 4$ and complex loci involving linked genes and alleles has been shown to exist on barley chromosomes [7]. A new ym5 gene conferring resistance to the new virus BaYMV-2 was also mapped at $1.1 \mathrm{cM}$ of MWG10. Additional crosses like L541 $\times$ W 122/37.1 $(y m 5)$ [7] or L541 $\times$ Franka (ym4) and investigations on F1 and F2 for progeny resistance, has to be performed to state clearly the relationships between $y m 4, y m 5$ genes and the one reported here. Moreover, we note a good correlation between hybridization experiments, results of visual scorings and serological tests. It is clear from these results that potential resistant parents to the new pathotype exist and that the probe detecting the $y m 4$ resistant gene can also be used to follow the gene responsible for resistance in segregation. Geographical deployment strategy is indicated in order to slow down the development of new pathotype through genetic vulnerability.

Acknowledgment: The authors thank Mr Maroquin and $\mathrm{Mr}$ Steyer for help in diagnostic evaluation, $\mathrm{Mr}$ Jestin for seeds, and thank Dr Graner for his gift of MWG10. We also wish to thank D. Mingeot and F. Delporte for reading the manuscript.

\section{REFERENCES}

[1] Adams M.J., Swaby A.G., Jones P., Occurrence of two strains of barley yellow mosaic virus in England, Plant Pathol. 36 (1987) 610-612.

[2] Batista M.F., Antoniw J.F., Swaby A.G., Jones P., Adams M.J., RNA/cDNA hybridization studies of UK 
isolates of barley yellow mosaic virus, Plant Pathol. 38 (1989) 226-229.

[3] Bendiek J., Davidson A.D., Schulze S.C., Schell J., Steinbiss H.H., Identification and classification of a resistance breaking strain of barley mosaic virus, Ann. Appl. Biol. 122 (1993) 481-491.

[4] Götz R., Friedt W., Resistance to the barley yellow mosaic complex - differential genotypic reactions and enetics of BaMMV - resistance of barley (Hordeum vulgare L.), Plant Breed. 111 (1993) 125-131.

[5] Graner A., Bauer E., RFLP mapping of the $y m 4$ virus resistance gene in barley, Theor. Appl. Genet. 86 (1993) 689-693.

[6] Graner A., Jahoor A., Schondelmaier J., Siedler H., Pillen K., Fischbeck G., Wenzel G., Herrmann R.G., Construction of an RFLP map of barley, Theor. Appl. Genet. 83 (1991) 250-256.

[7] Graner A., Bauer E., Kellermann A., Proeseler G., Wenzel G., Ordon F., RFLP analysis of resistance to the barley yellow mosaic virus complexe, Agronomie 15 (1995) 475-479.

[8] Hariri D., Fouchard M., Lapierre H., Resistance to barley yellow mosaic virus and barley mild mosaic virus in barley, Proc. 1st Symp. Int. Working Group Plant Viruses with Fungal Vectors, Braunschweig, 21-24 August, 1990, pp. 109-112.

[9] Heun M., Kennedy A.E., Anderson J.A., Lapitan N.L.V., Sorrells M.E., Tanksley S.D., Construction of a restriction fragment length polymorphism map for barley (Hordeum vulgare), Genome 34 (1991) 437-447.

[10] Hill S.A, Evans E.J., New or unusual records of plant diseases and pests, P1 ant Pathol. 29 (1980) 197-199.

[11] Huth W., The Barley yellow mosaic virus diseases in the Federal Republic of Germany. Observations since 1978, Nachrichtenbl. Deutscher Pflanzenschutzdienst 36 (4) (1984) 49-55.

[12] Huth W., Barley yellow mosaic - a disease in Europe caused by two different viruses, in: Cooper J.I., Asher M.J.C. (Eds.), Developments in Applied Biology 2, Viruses with Fungal Vectors, AAB Office, Institute of Horticultural Research, Wellesbourne, Warwick, UK, 1988.

[13] Huth W., Verbreitung der Gelbmosaikviren, BaYMV, BaMMV and BaYMV-2 und Screening von Gerstensorten auf Resistenz gegenüber BaYMV-2,
Nachrichtenbl. Deutscher Pflanzenschutzdienst 43 (1991) 233-237.

[14] Huth W., Adams M.J., Barley Yellow Mosaic Virus (BaYMV) and BaYMV-M: two different viruses, Intervirology 31 (1990) 38-42.

[15] Huth W., Leseman D.E., Eine für die Bundesrepublik neue Virose an Wintergerste, Nachrichtenbl. Deutscher Pflanzenschutzdienst 30 (12) (1978) 184-185.

[16] Kleinhofs A., Killan A., Saghai Maroof M.A., Biyashev R.M., Hayes P., Chen F.Q., Lapitan N., Fenwick A., Blacke T.K., Kanazin V., Dahleen L., Kudrna D., Bollinger J., Knapp S.J., Liu B., Sorrells M., Heun M., Franckowiak J.D., Hoffman D., Skadsen R., Steffenson B.J., A molecular, isozyme and morphological map of barley (Hordeum vulgare) genome, Theor. Appl. Genet. 86 (1993) 705-712.

[17] Kummert J., Viroses transmises par Polymyxa. Le diagnostic des agents viraux : techniques immunologiques et hybridation moléculaire. I. Diagnostic et caractérisation des agents de la mosaïque jaune de l'orge par le test sérologique Elisa, Parasitica 49 (3-4) (1993) 69-87.

[18] Kummert J., Lemaire J.L., Rufflard G., Colinet D., Lepoivre P., Detection and characterization of a barley yellow mosaic virus isolate susceptible to infect the resistant barley cultivar Express, Arch. Int. Physiol. Biochem. 102 (1993) B 17.

[19] Lapierre H., Nouvelles maladies à virus sur céréales d'hiver, Producteur agricole français 56 (270) (1980) 11.

[20] Maroquin C., Cavelier M., Rassel A., Premières observations sur le virus de la mosaïque de l'orge en Belgique, Bull. Rech. Agron. Gembloux 17 (1982) 157-176

[21] Ordon F., Friedt W., Mode of inheritance and genetic diversity of BaMMV resistance of exotic barley germplasms carrying genes different from $y m 4$, Theor. Appl. Genet. 86 (1993) 229-233.

[22] Steyer S., Froidmont F., Kummert J., Characterization of a resistance-breaking BaYMV isolate from Belgium, Agronomie 15 (1995) 433-438.

[23] Usugi T., Kashiwazaki S., Omura T., Tsuchizaki T., Some properties of nucleic acids and coat proteins of soil-borne filamentous viruses, Ann. Phytopath. Soc. Japan 55 (1989) 26-31. 